\title{
ATTITUDES OF THE SOVIET UNION AND GERMANY TOWARDS THE QUESTION OF VILNIUS BETWEEN THE WORLD WARS
}

\author{
ZENONAS BUTKUS
}

ABSTRACT. The aim of this article is to examine the attitudes of the Soviet Union and Germany towards the problem of Vilnius in the period between the First and Second World Wars. The article is based mainly on unpublished documents from Lithuanian, Latvian, Estonian, German and Soviet archives. The problem under review emerged after the First World War, when Poland occupied the capital of Lithuania, Vilnius, and kept it under its control almost until the Second World War. Lithuania refused to recognize the situation, and between the two countries there arose a conflict, which was instigated by the Soviet Union and Germany, as they did not want the Baltic States and Poland to create a defence union.

The Soviet Union and Germany worked hand in hand in dealing with this conflict. In the process of its regulation they acquired quite an extensive experience in diplomatic co-operation, which they applied successfully in establishing the spheres of their influence in the Baltic States in 1939.

We are approaching a new millennium facing various international conflicts, which not only hinder progress, but also create a threat to the existence of smaller nations. Usually only the conflicting sides are blamed about the never-ending disturbances. Little attention is paid to the impact of the policies of the great powers on these conflicts, though this is a major determinant of the course of the international relations. If we understood these policies, we would notice the causes of the conflicts more easily, and it would be much easier to solve them.

Historical experience would be of great use in finding the causes of the conflicts. In the case under consideration the territorial interstate conflict between Lithuania and Poland is of great importance. It arose due to Poland's occupying and controlling the capital of Lithuania Vilnius throughout the period from 1920 until the Second World War. 
This conflict was influenced by the great powers, especially the neighbouring ones - the Soviet Union and Germany. At that time the arguing sides, especially the weaker and victimized one, Lithuania, were blamed. This attitude is still current nowadays, and is even penetrating into historical scholarship. The conflict over Vilnius is often presented as an example of how the young states in Central and Eastern Europe, which appeared after the First World War, did not manage to live in peace, constantly went into conflicts, and therefore it was only their own fault that they lost their independence at the beginning of the Second World War or before it.

However, the truth is that most of the young states managed perfectly to live next to each other. For instance, Lithuania, Latvia and Estonia delineated their borders in 1920-1 and never had any territorial disagreements. It was Poland which had most of such conflicts, and that was due to its endeavours to become a great power or at least to pursue a corresponding policy.

Losing Vilnius was a tragedy for Lithuania. At times the return of Vilnius seemed even more important than the retaining of the independence itself, at least to some of the Lithuanian politicians. Regaining the capital city became the most important issue in Lithuania's foreign policy. In order to understand that policy it is important to carefully investigate the problem of Vilnius.

Actually, there are quite a lot of works dealing this problem. The attitude of the great powers was also discussed. It was investigated in the works of Alfred Erich Senn ${ }^{1}$, Regina Žepkaitė, Česlovas Laurinavičius, Piotr Lossowski ${ }^{2}$ and other historians. Among recent researches, Jurgen Pagel's article and monograph are of particular informativeness and appropriateness for our subject, as the attitude of the Soviet Union towards the question of Vilnius is revealed in them. ${ }^{3}$ However, until now the policies towards this question of the Soviet

${ }^{1}$ A. E. Senn, The Great Powers, Lithuania and Wilna Question. 1920-1928 (Leiden, 1966).

${ }^{2}$ R. Žepkaitè, Diplomatija imperializmo tarnyboje. Lietuvos ir Lenkijos santykiai 1919-1939m. (Vilnius, 1980); R. Žepkaité, 'Die fehlende Hauptstadt: Litauens Politik im Zeichen der Wilnafrage', Nordost-Archiv. Zeitschrift fur Regionalgeschichte, H. 2 (1993); Č. Laurinavičius, 'Vilniaus klausimas', Politika ir diplomatija (Kaunas, 1997); P. Lossowski, Konflikt polsko-litewski 1918-1920 (Warsaw, 1996); P. Lossowski, 'Das Wilna-Problem in der polnischen Aussenpolitik 1918-1939', Nordost-Archiv, H. 2 (1993); P. Lossowski, Stosunki polsko-litewskie 1921-1939 (Warszawa, 1997); etc.

${ }^{3}$ J. Pagel, 'Der polnisch-litauische Streit um Wilna und die Haltung der Sowietunion 1918-1938', Jahrbücher für Geschichte Osteuropas, 40, H. 1 (1992); J. Pagel, Polen und die Sowjetunion 1938-1939 (Stuttgart, 1992). 
Union and Germany were analysed separately. Therefore, it could be sensible to investigate the policy of those countries together and to see how their common policy affected the problem of Vilnius.

The main sources for this article are the archives of Lithuania, Germany and the Soviet Union and two largest collections of documents: Akten zur deutschen auswärtigen Politik 1918-1945, and Документы внешней политики СССР.

The Origin of the Problem and the Influence of Germany and the Soviet Union on its Rise

The Vilnius problem became particularly critical after the First World War, when both the emerging Lithuanian state and Poland were claiming the old Lithuanian capital. The latter managed to organise a more powerful army, so on 21 April 1919, it occupied Vilnius, driving the Bolsheviks away from it. Vilnius was returned to Lithuania according to the Peace Treaty with the Soviet Russia on 12 July 1920 , and stayed under its rule during August and September of the same year. However, the Polish army treacherously occupied Vilnius, annexed it and kept under its rule until the Second World War. Lithuania strongly resisted the occupation, and even refused to have any relations with Poland at all, unless the latter returned Vilnius. The confrontation between the two countries became so bitter because it was not just an ordinary territorial conflict. The existence of the Lithuanian state and nation was threatened. Most of the Polish politicians underestimated the national revival, which was taking place in Lithuania in the nineteenth century, they did not want to acknowledge the emergence of an independent (and separate from Poland) Lithuanian nation, and of course, the existence of an autonomous Lithuanian state. They believed that this state had to remain dependant on Poland in one way or another, and they supported the re-establishment of the historical, even though more modern, federation of Lithuania and Poland.

Meanwhile, Lithuanian politicians often emphasized that they renounced their claims to the lands of the Grand Duchy of Lithuania and were re-creating their state within its ethnic territory. As a matter of fact, the ethnic principle, as Č. Laurinavičius has stated, 'would hardly correlate' with the self-determination of nations, ${ }^{4}$ which, by the way, was impossible to accomplish in that situation, in the circumstances of an actual war. Besides, the Lithuanian politicians argued that in recreating a state one has to slightly adjust the ethnic principle for economic or strategic reasons, especially taking into account the

${ }^{4}$ Č. Laurinavičius. Politika, p. 17 
Slavonized population of Eastern Lithuania. It was a national Lithuanian state that was being re-created, and hardly any ways were seen in which Polish- and Belorussian-speaking parts of the population could be adequately integrated into it.

Thus, the .Vilnius problem was complicated due to different conceptions of state re-creation in Lithuania and Poland, and different attitudes towards their common historical statehood and its continuity. Lithuania was striving to re-create a state with Vilnius as its capital, while Poland was liable to return it to Lithuania only in case the latter would form a federation with Poland.

It is usual to think that the great powers, which determined the international situation at that time - Great Britain, France, the Soviet Union and Germany -tried to interfere, influence or regulate the Vilnius conflict only after its emergence. Actually, however, these states directly or indirectly had contributed to the very emergence and advancement of the conflict. For instance, Great Britain and France created conditions for it to rise by their different attitudes towards the Lithuanian and Polish states at their political re-emergence after the First World War. Poland was at once recognized as a normal and competent state, whereas the recognition of Lithuania was withheld for a long time; its representatives were not allowed to take part in the Paris Peace Conference, and even there were considerations to hand it over to Russia or to Poland itself. Therefore it was much easier for Poland than for Lithuania to re-create the state and to expand the territory. The Western politicians could in no way understand that Vilnius for Lithuania is of vital importance as the capital city, which can not be relinquished. They kept making concessions to Polish aggression, acknowledging its occupations one after another. On 15 March 1923, when the Conference of Ambassadors acknowledged that Vilnius belonged to Poland, the feelings of the entire Lithuanian nation were hurt, and therefore the conflict was sharpened for many years.

Once the Allied Powers unequivocally declared themselves to be on the side of Poland, the Soviet Union and Germany had good reason for coming to the defence of the victimized side and under the pretext of defending Lithuania they justified their own revanchist policies.

It may seem at first sight that, as the Allies supported Poland and the Soviet Union and Germany supported Lithuania, they created a balance of forces, and therefore the conflict could exist. But actually, the Soviet Union and Germany only encouraged the rise of the conflict not by supporting Lithuania, but by supporting it too little, not at the proper time, or only allegedly supporting and often selfishly profiteering in the question of Vilnius, which was so painful for 
Lithuania. Recently, German assistance for Lithuania has often been praised. However, it must be remembered that in the spring of 1919 the Germans refused to help Lithuania liberate Vilnius from Bolshevik occupation. That determined that Vilnius was taken by the Poles and not the Lithuanians in 1919.

The point was that the leadership of the Lithuanian army had decided to start the operation of occupying Vilnius on 27 March. But at that time the army was still being created, and it was badly in need of weapons, and in particular, artillery. Therefore the Lithuanian government addressed the German military and civilian authorities, and also the government of that country with the request of two batteries of guns and two infantry battalions to support the march of Lithuanian troops to Vilnius. Jurgis Alekna, the special commissioner of the Lithuanian government, went to Berlin to negotiate for this support. ${ }^{5}$ However, the negotiations were difficult. It took the Lithuanian representatives a lot of time and patience to persuade the Germans that the support requested was quite insignificant, that the Lithuanian army itself was ready to occupy Vilnius, whereas the German battalions would only have to protect the march, actually they would be in the reserve. If the operation was successful, the Germans would have no new trouble - the Lithuanians would manage to protect Vilnius and to resist the Bolsheviks along the new front. Besides, the Germans were guaranteed that they would not to get involved in fights with the Poles even if they took part in the liberation of Vilnius. They were only asked if they could provide the liberated city with some food. ${ }^{6}$

There were different reactions to this request from different institutions of Germany: the Ministry of Foreign Affairs tended to fulfil it, but the military authorities rejected it. ${ }^{7}$ The final decision was made by the German government. At the session of 22 March 1919 it was decided after special consideration that Germany should not support Lithuania in the liberation of Vilnius. The only member of the government who proposed helping the Lithuanians was Matthias Erzberger. ${ }^{8}$

${ }^{5}$ LCVA, f. 383, ap. 7. b. 628. 1. 198.

${ }^{6} \mathrm{Cf}$. the letters of the Lithuanian prime minister and the embassy in Berlin of March 1919 to the government of Germany. Ibid., b. 60, 1. 169-170, 182-183; the March 1919 documents of the German legation in Kaunas, Politisches Archiv des Auswärtigen Amtes in Bonn (henceforth - PAAA), Gesandtschaft Kowno, 134/2.

${ }^{7} \mathrm{P}$. Grupp, Deutsche Aussenpolitik im Schatten von Versailles 1918-1920 (Paderborn, 1988), S. 273-274.

${ }^{8}$ Akten der Reichskanzlei. Weimarer Republik. Das Kabinett Schneidemann (13. Februar bis 20. Juni 1919). (Boppard am Rhein, 1971), S. 91. 
One can not see clearly what were the motives of those who suggested rejecting the Lithuanian request, as the minutes of the session are rather laconic and not written in short hand. However, the analysis of the collected archival documents indicates that military considerations were of major importance. Germany perceived the occupation of Vilnius as a strategically inconvenient action, since in that case the front line with the Bolsheviks would bulge eastwards there, and more troops would be necessary to protect it - this was the reasoning of the German military leadership. Meanwhile, a German General Staff officer, who was serving in the Lithuanian army at that time and who took part in planning the operation to liberate Vilnius, was sure that that assistance that Lithuania requested would have been sufficient to make the operation successful. The Red Army, which was fighting with Poland and Latvia at that time, would not have managed to counter-attack and take Vilnius back. After occupying it, Lithuanian forces would have been absolutely sufficient to keep defend the city. The German government was aware of that situation, ${ }^{9}$ however, since the Vilnius region was not in their interests at that time, they did not pay any attention to it. The government was much more concerned with the defence of the Latvian and Estonian lands, long since inhabited by rich Germans, and keeping Kaunas and Samogitia in their hands was enough for that purpose.

The Germans did not help Lithuania liberate Vilnius for one more reason - they tried to avoid confrontation with Russia. They thought that occupying Vilnius would have been a great challenge to Russia, which even at that time was considered to be the main German ally in the future struggle against the victors of the war -Great Britain and France.

In the Lithuanian-Polish conflict Germany did not always side with Lithuania. Quite often it manoeuvred between the two sides. Even at the beginning of 1918 Poland asked Germany to let the Polish army pass through Grodno towards Vilnius. In return they promised to create good conditions for the German soldiers returning home through Poland. Soon a compromise was reached. On 5 February 1919 Poland and Germany signed a treaty in Białystok, according to which Grodno, the railway line Białystok-Brest and some other lines, which had previously belonged to the German military administration, were handed over to the Polish troops. This treaty enabled the Polish army to move rapidly towards Vilnius and occupy it. The Germans knew that by not helping the Lithuanians and by letting the Polish pass by they gave Vilnius to Poland, and that can be proved by the

${ }^{9}$ PAAA, Gesandtschaft Kowno, 134/2 (pages unnumbered). 
fact that in the German government session of 22 March 1919, a question was raised explicitly: Will Lithuania be rendered help to take Vilnius and to protect it from the Polish occupation? ${ }^{10}$

So Germany's creating conditions for Poland to occupy the capital of Lithuania in a way enabled the rise of the future conflict.

The Soviets contributed even more to the flare-up of the conflict. They practically provoked it. According to the Peace Treaty with Lithuania of 12 July 1920, the Soviet Union assigned Vilnius to Lithuania, however, according to the Peace Treaty with Poland (preliminarily signed on 12 October 1920, and finally - on 18 March 1921) it was practically ascribed to Poland as well, as the border line between the two states ran a little further to the east of the borders between Russia and Poland as stated previously. ${ }^{11}$ In other words, the same territory, including Vilnius, was first attributed to Lithuania, and soon after that (with some other areas) - to Poland.

True, the Peace Treaty with Poland stated that that territory was the object of dispute between Lithuania and Poland. Exact borders of the disputed area were not established, but, as seen from the actual situation and later claims of the sides that signed the Treaty, according to Č. Laurinavičius, Vilnius was included into it. ${ }^{12}$ So in fact the Soviet Union first ascribed it to Lithuania, and afterwards stated that it was an unsettled border dispute between Lithuania and Poland. Moreover, the Peace Treaty with Poland indicated that it was Lithuania and Poland alone that had to divide that area, with no one else interfering. ${ }^{13}$ This clearly reminds of an imperialistic division of the spheres of influence: using this kind of formulation the Soviet Union allowed Poland to treat Lithuania in any way it would wish to - actually, to keep Vilnius to itself. Of course, the Soviets did not want to leave Lithuania under Polish influence, so they kept declaring that Vilnius would legally belong to Poland only when Lithuania agreed to that. In that way, by signing treaties with Lithuania and Poland, the Soviet Union created a very subtle legal mechanism, escalating conflict over Vilnius between the two states.

The chronological coincidence of the peace talks and the development of this conflict indicates that the mechanism did not occur by accident, but was formed deliberately, as the principal agreement on the Russian-Polish border was reached on 5 October 1920, i.e., at

${ }^{10}$ Akten der Reichskanzlei. Weimarer Republik, S. 91.

${ }^{11}$ See texts and maps of the Treaty in Документы внешней политики СССР (hereafter - ДВП), t. 3 (Moscow, 1959), p. 28-42, 245-258, 618-660.

${ }^{12}$ Laurinavičius, Politika, p. 135

${ }^{13}$ ДВП, t.3, c. 623 
the time when the Poles were preparing for the occupation of Vilnius, led by Lucjan Żeligowski. This decision was confirmed by the preliminary peace treaty of 12 October, i.e., straight after Żeligowski occupied Vilnius on 9 October. This means that the occupation of Vilnius was synchronised with the Polish-Soviet negotiations, and besides, the negotiations themselves seem to have been affected by the preparation for the occupation: they dragged for quite a long time, both sides presented mutually unacceptable demands, and suddenly on the day before Żeligowski's aggression, all the disagreements, including the territorial ones, were urgently settled and solved.

Somehow these coincidences have been ignored in historiography. Żeligowski's aggression was usually linked to the Lithuanian-Soviet Peace Treaty rather than to the Polish-Soviet one. Lithuania was mostly blamed for the appendix of the second clause of the Peace Treaty, which stated that the Red Army's entering the territory assigned to Lithuania would not be considered a breach of the Treaty. When the Treaty was signed, Poland and the Soviet Union were at war, towards which Lithuania had declared neutrality. It meant that Lithuania abandoned neutrality by allowing the Red Army, which was attacking Poland, to use its territory. Laurinavičius even maintained that the appendix of 12 July became a convenient pretext to ignore the Allies' proposal received just a day before to halt the Red Army attacks; the appendix allegedly meant 'the Lithuanian permission' not to do so. ${ }^{14}$ However, the Soviet Union attacked Poland not only through the territory assigned to Lithuania, but along the whole frontline. Besides, Lithuania had not yet taken control of the territory, when the Red Army entered it without any permission. The Soviet Union was much more concerned about the success of its military operations rather than about the peace treaty with Lithuania. The latter had no possibility to sign the treaty without the appendix. The Lithuanian delegation was overtly warned in Moscow: "we either sign the treaty with the appendix or we do not sign it at all'. ${ }^{15}$

Of course, this does not justify the actions of Lithuania, the more so that it conducted negotiations for a military treaty with the Soviet Union, even though it was not signed. The first Soviet ambassador, Aleksandr Akselrod, on arriving at Lithuania at the end of

${ }^{14}$ Č. Laurinavičius, 'Geopolitikos ir demokratijos dilema: moderniosios Lietuvos užsienio politika ir Steigiamasis seimas', Steigiamajam Seimui-80. 19201922 metu parlamentiné patirtis: sprendimu politika, tikslai, aplinkybès (Vilnus, 2000), p. 36.

${ }^{15}$ Č. Laurinavičius, Lietuvos-Sovietu Rusijos taikos sutartis (Vilnius, 1992),

p. 150 . 
1920, tried hard to involve the country into a military collaboration with Moscow. ${ }^{16}$ As stated by Laurinavičius, 'the tendencies in the Lithuanian policy to enter into an alliance with the Soviet Union were the necessary pretext for Żeligowski's action' ${ }^{17}$ Nevertheless, the direct reasons of the action should rather be linked, as mentioned above, to the relations between Poland and the Soviet Union. The contemporary Lithuanian politicians could rather be blamed for relying too much on the support of the Soviet Union in their attempts to recover and protect Vilnius, since Soviet promises were only declarative and often provoking conflicts with Poland. Probably too little attention was paid to the negotiations with Poland and the Western countries. After experiencing a bitter disdain at the Paris Peace Conference, Lithuania did not send its representatives to the conference at Spa, which took place in 1920, and where Lithuania could have expected a more effective support on the Vilnius issue. But most of all Lithuania should be blamed for not giving autonomy to the Vilnius territory recovered in 1920 and not taking care about its proper defence. After driving out Bermondt's troops, Lithuania carelessly reduced and weakened its army, and at the time of Żeligowski's onslaught it had only about 16,000 soldiers, nearly as much as Żeligowski himself. Some Lithuanian military experts and politicians considered that about 40,000 soldiers would have been sufficient to protect Vilnius and maintain its neutrality in the RussianPolish war. ${ }^{18}$

Soviet historians used to emphasize that Russia was very helpful in defending Lithuania from Żeligowski's aggression, and even offered it military support, but Lithuania refused it. However, the archives indicate that the situation was just the opposite. As I have showed on another occasion, the Soviet Union did not offer any military support, and Lithuania did not refuse it, but asked for it, but the Soviet Union turned down the request. ${ }^{19}$ It was not in the interests of the Soviet Union to fight with Poland after having ecouraged Żeligowski to attack Vilnius. The Soviets were only concerned about the continuation of the Lithuanian-Polish conflict and Lithuania's constant appeals for help. But for this purpose the diplomatic efforts were quite sufficient, and military intervention was not necessary.

${ }^{16}$ Z. Butkus, 'Pirmasis Sovietu pasiuntinys Lietuvoje A. Akselrodas: diplomatinès veiklos pusmetis (1920 m. rugsèjis - $1921 \mathrm{~m}$. kovas)', Lietuvos istorijos metraštis. 1996 metai (1997), p. 120-136.

${ }^{17}$ Laurinavičius, Taikos sutartis, p. 143.

${ }^{18}$ Z. Butkus, Lietuvos Respublikos ministrai pirmininkai (1918-1940). (Vilnius, 1997), p. 241.

${ }^{19}$ Butkus, 'Pirmasis Sovietu pasiuntinys', p. 126-128 
German assistance was also grossly exaggerated in this context. The thing was that during Żeligowski's aggression a rumour was spread among European politicians and diplomats and in the press that the German army was helping Lithuania to fight against that aggression. Foreign diplomats, accredited in Poland and the Baltic States, were anxiously writing in their reports that German troops in thousands were going to Lithuania, that they went straight to the frontline, that the army of about 70-100 thousand, concentrated in Eastern Prussia (about 30-35 thousand at Virbalis), was about to enter Lithuania. ${ }^{20}$ Due to such reports, which actually were baseless rumours spread by Poland, a paradoxical situation developed. When Żeligowski invaded Lithuania, the European diplomats and the press did not condemn the aggressor, but quite on the contrary, they blamed Lithuania, which, presumably unable to resist Żeligowski on its own, allowed the Germans to enter its territory, creating a dangerous situation for its neighbours and even causing a threat for the stability of the whole Europe. International organisations believed in that rumour, too. For instance, the commission of the Allied military control in Berlin received an order to check the trustworthiness of the rumours, and besides, to stop all the trains carrying soldiers and ammunition towards Eastern Prussia. ${ }^{21}$

No data witnessing the German military support for Lithuania during the Żeligowski's aggression were found either in German archives or in those of the Baltic States. On the contrary, the sources show that no support was given. Germany decided to adopt a policy of neutrality in the Lithuanian-Polish conflict and was about to declare it officially, but did not do that due to formal reasons - due to the fact that Poland, trying to camouflage its support for Żeligowski, did not consider itself at war with Lithuania. ${ }^{22}$ Officially Germany did not even sell arms to Lithuania. The Lithuanian military delegation, which stayed in Germany since September 1920, had to buy arms in secret and transport them across the border illegally. ${ }^{23}$ Nor did Germany not only help Lithuania fight Żeligowski, but it also avoided any closer military relationships. For instance, in 1921 Germany deliberated for quite a long time whether to allow several Lithuanian officers to study in German military schools. ${ }^{24}$

${ }^{20}$ A report of the Latvian ambassador in Lithuania, Vilis Bandrevics, could serve as an example. Latvijas Valsts vēstures arhīvs, f. 2574, apr. 3, 1. 80s, lp. 210, 371, 374.

${ }^{21}$ Žepkaitè, Diplomatija, p. 132.

${ }^{22}$ Akten zur Deutschen Auswärtigen Politik 1918-1945 (henceforth ADAP), Serie A, Bd.4 (Göttingen, 1986), p. 51-52.

${ }^{23}$ Žepkaitè, Diplomatija, p. 131-132.

${ }^{24}$ ADAP, Serie A, Bd. 5, p. 49, 305. 
Germany and Russia coordinated their attitudes towards Zeligowski. For example, on 19 November 1920, the Soviet ambassador in Berlin, Viktor Kopp, discussed those attitudes with a representative of the German Ministry of Foreign Affairs, Adolf Georg Otto Maltzan. Both officials agreed that their countries felt sympathy for Lithuania in its struggle against the 'usurper Żeligowski', but they were not going to offer any military support to it. True, Kopp asked if it were not possible 'to sell at a lower price to Lithuania the military materials (arms, horses, uniforms), taken from the Red Army soldiers, interned in Germany'. ${ }^{25}$ However, Maltzan disapproved of such terms because Germany had to maintain a policy of strict neutrality.

The comparison of the German and Soviet attitudes towards Żeligowski with the attitude of another neighbouring country - Latvia shows that the latter was much better disposed towards Lithuania. The Latvian government issued an ultimatum to Poland, stating that, if Żeligowski attacked Kaunas, Latvia with all of its army would stand by Lithuania. ${ }^{26}$ Besides, quite a lot of Latvian officers (even several colonels among them) were in the service of the Lithuanian General Staff, preparing the army for the defence against Poland. Neither German nor Russian officers played such a role.

Of course, Soviet diplomatic and political support for Lithuania should not be underestimated. But that support was selfish, it pushed Lithuania towards the anti-Western orientation and did not encourage the settlement of the Vilnius conflict. In its notes of 30 October, 26 November, 11 December 1920 and 30 January 1921, the Soviet Union denounced Żeligowski's aggression, claiming that Vilnius belonged to Lithuania. However, at the same time it fiercely protested against the use of the forces of the Western and Scandinavian countries in the territory of Vilnius in order to oversee the intended plebiscite. It was planned by the Council of the League of the Nations at the end of October 1920, and the formation of the troops to be sent to Vilnius was started. Some countries, e.g., Sweden, had already formed such troops, ${ }^{27}$ but Lithuania, in regard to the Soviet position, refused to conduct a plebiscite in Vilnius and the surrounding area in the middle of February 1921.

The Soviet Union greatly contributed to the frustration of another plan to end the Vilnius conflict, the so-called Hymans project, proposed

${ }^{25}$ Ibid., Bd. 4. S. 96.

${ }^{26}$ Z. Butkus, Lietuvos ir Latvijos santykiai 1919-1929 metais (Vilnius, 1993), •p. $45-47$.

${ }^{27}$ S. Pivoras, 'Lietuvos-Lenkijos konfliktas dèl Vilniaus ir Švedija (1920-1924 m.)', Kultūros barai, 6 (2000), p. 57-58. 
by the League of the Nations during the negotiations between Lithuania and Poland in Brussels and Geneva in 1921. The project was to balance the interests of both conflicting sides: Lithuania was to regain Vilnius, but in return very close, actually federal relations had to be established between the two countries. As the project was seen as a threat to Lithuanian sovereignty, broad sections of society and many political parties disapproved of it, although some politicians understood that it is the only and probably the last opportunity to recover Vilnius through the mediation of Western countries. That was the opinion of the Prime Minister of that time, Kazys Grinius, and members of his cabinet Ernestas Galvanauskas and Jonas Šimkus. In his memoirs Kazys Grinius wrote: 'The members of my Cabinet (...) did not entirely oppose the Hymans project, at least there would have been a necessary majority to accept it' ${ }^{28}$ However, pressure on the Lithuanian government from the outside was enormous -Soviet Russia explicitly insisted on rejecting the Hymans project, because it understood that if it was implemented, Western influence in the Baltic States would grow stronger, the conflict between Poland and Lithuania would be eliminated, and a union of these two countries would be established, which in the future could check Soviet expansionism westward.

The extent of the pressure could be illustrated by some extensive quotations from the messages of Jurgis Baltrušaitis, the Lithuanian ambassador in Moscow, sent to the Lithuanian government at the time when the Hymans project had to be discussed. On 31 October 1921, Baltrušaitis wrote to the Foreign Minister of Lithuania Juozas Purickis:

In today's talk with the Russians it is the same old story: never ever closer contacts with the Poles, beware even of the remotest co-operation... Is it true that you personally feel disposed to vote for the Hymans project? Please telegraph me... As far as my feeble voice can do and your interests can reach, I advise and beg you to keep as far away from the Poles as possible. For the Allies Lithuania is like a cork to stop a hole temporarily. Later they will throw us away like a stopper. Meanwhile Russia is changing ..., it ... will regain its old voice ... we will be trampled down ... God, give us wisdom, for the last fateful hour has really come. ${ }^{29}$ Such alarming messages were sent frequently, sometimes even several times a day. For example, two messages of 27 November read:

The Soviet government strictly advised the Lithuanian government in no way to accept the Hymans project and to beware of the remotest 'co-operation' with the Poles. The Soviet government,

${ }^{28}$ K. Grinius, Atsiminimai ir mintys (a manuscript), vol.4, p. 352, LCVA, f. 659 , ap. 1 , b. 5 .

${ }^{29}$ LCVA, f. 383, ap. 7, b. 108, 1. 35. 
in the interests of Lithuania and itself, is expecting that Lithuania in no way will accept the Hymans project. If that happened, Russia would consider Lithuania to have performed a hostile act. The Soviet government firmly believes that if Lithuania rejects the Hymans project, Poland will have neither possibility or nor courage to attack Lithuania. If that happened, the Soviet Russia would not indifferently witness that, but would take the harshest means in order not to allow Lithuanian independence to be disdained or its body torn... Even today we can talk about the support in arms, money, etc. By the way, seeing a threat for Lithuania, the Soviet Union has contacted Germany and is looking for a proper form of co-operation in order to eliminate our trouble... I am very well informed from authentic sources and I announce the following: the Russians are going towards a personal dictatorship of two - Lenin and Trotsky, or, possibly, three - Lenin, Trotsky and Dzierzhinsky... The bellicose party of Trocky is so strong that one can expect a war to start every day... Everything is ready... Three cavalry armies have been gathered, all in all nearly 200,000 men. They are going to attack Poland late in winter... the Russians still are a force, and a cruel force. This is a true fact. Poland will be attacked in an inhumane way, using barbarian methods. A special Cheka for Poland has already been formed of terribly revengeful individuals... those Cheka people have sworn to sweep Poland with the iron broom.

The messages quoted were not based on the personal opinion of Baltrušaitis, his invention, but they were the position of the Soviet government, conveyed authentically. That is proved by the documents of the People's Commissariat of Foreign Affairs, which have survived in the Russian archives, in which, in addition to other things, the feverish activities of the then Soviet ambassador in Lithuania Semen Aralov are seen. Actually he told the Lithuanian leaders the same things as the Soviet politicians told Baltrušaitis. The usual diplomatic pressure, an emphatic assertion that accepting the Hymans project would be an action hostile to Russia, was not the limit. Traditionally, carrot and stick policy was pursued. The Soviets threatened that Poland would be attacked and cruelly devastated. That meant that the same would happen to Lithuania if it accepted the Hymans project and in that way formed a union with Poland. And if it rejected the project, it would get the Soviet support to defend from Poland.

Such pressure was hard for Lithuania to resist, especially because of the fact that the Hymans project itself seemed risky, even dangerous, as Poland did not make any concessions. On rejecting the project, Lithuania could not think of anything more original than to 
resort again to the Soviet position. Lithuania asked for an official note directed against the Hymans project ${ }^{30}$ and received it on 15 September 1921. The note emphasised that during the negotiations in Geneva France and other Western countries and the League of the Nations were pushing Lithuania towards a coalition with the states hostile to the Soviet Union and that the Soviets would not reconcile themselves with that. ${ }^{31}$ The Soviets were pleased about Lithuania's rejection of the Hymans project and on that occasion they sent it a most benevolent, almost congratulatory note. ${ }^{32}$ On 24 December Lithuania informed the League of the Nations about its final decision to decline the project. ${ }^{33}$ In its 1921 report presented at the 9th Congress of the Soviets of Russia, the People's Commissariat of the Foreign Affairs estimated the action of Lithuania as one of the best achievement of its work, emphasizing the fact that Lithuania had been warned many times that accepting the Hymans project would be an act hostile to Russia. ${ }^{34}$

The effectiveness of the Soviet pressure was greatly augmented by the fact that, as mentioned in the messages of Baltrušaitis quoted above, it was exerted in co-operation with Germany - by these two great powers. True, German pressure on Lithuania was not so intense as Soviet pressure, it was deliberately unofficial and often limited to indications that the Russian opinion on the issue (which was strictly negative) ought to be taken into consideration. However, Germany, too, did not disguise its disapproval of the Hymans project, because it understood that if Lithuania and Poland formed a union, they would be an obstacle in the German expansion to the East, as well as for the Soviets to the West.

Following the failure of the Hymans project, the League of the Nations and the Western countries in general paid less attention to the solution of the Vilnius question in the way acceptable for the both sides and accepted the contemporary situation - they allowed Poland to carry out the election in the occupied Vilnius territory and to actually annex it. The League of the Nations eliminated the neutral zone between Lithuania and Poland, and on 15 March 1923, the Conference of Ambassadors recognized the eastern border of Poland, thus assigning Vilnius to Poland. The Soviet Union protested against that decision and did not consent to it, and so did Lithuania. Nevertheless, the decision remained in force.

${ }^{30}$ ДВП, т. 3. p. 331.

${ }^{31}$ Ibid., p. 338-339.

${ }^{32}$ Ibid, p. 489.

${ }^{33}$ See the text of the note in Lietuva, 31 Dec. 1921

${ }^{34}$ ДВП,. т. 3. p. 696 
Thus, the issue of Vilnius, with the active participation and instigation of the Soviet Union and Germany, turned into a bitter interstate conflict between Lithuania and Poland, and disrupted the unity of the Baltic states, weakened their defences and created the conditions for the two great powers to prepare for their new expansion.

The Solution of the Conflict and Its Exploitation for the Occupation of Poland and the Baltic States

Throughout almost the entire period between two World Wars, the conflict between Lithuania and Poland over Vilnius was considered by the Soviet Union and Germany a most convenient tool in manipulating their influence in Central and Eastern Europe. The solution of the Vilnius question, the reconciliation of Lithuania and Poland and their rapprochement, which should have a logical outcome of the events, seemed to both great powers as the worst possible scenario. In order not to let that happen, they tried to instigate the conflict, and often did that hand in hand. One of the programme documents of the German Ministry of Foreign Affairs, which was prepared by 1919, emphasized that the conflict between Lithuania and Poland was desirable, as Lithuania would constantly seek the aid of Germany in its struggle for Vilnius, and that would make it possible to activate Eastern policy in general. ${ }^{35}$ A similar document of Soviet diplomacy also read in 1921: 'The longer the Lithuanian-Polish conflict lasts, the better it is for us, and therefore it must be instigated'. ${ }^{36}$ While escalating the conflict, particular attention was paid to every attempt and tendency to solve it, and all such initiatives were paralysed at the very beginning. For example, on 19 February 1923, Secretary of the German Ministry of Foreign Affairs Maltzan informed the Lithuanian ambassador in Berlin Vaclovas Sidzikauskas that he found out about the Polish and Lithuanian plans to negotiate the issue of Vilnius and other territories and informed the German representative in Kaunas Franz Olshausen, and Moscow about that. That was a convincing indication that neither Germany nor the Soviet Union would favour such negotiations. Sidzikauskas immediately informed the Lithuanian Prime Minister and Minister of Foreign Affairs Ernestas Galvanauskas about this conversation, ${ }^{37}$ and it was accepted as a warning for Lithuania not to enter into negotiations with Poland over the issue of Vilnius.

${ }^{35}$ P. Grupp, Deutsche Aussenpolitik, p. 276.

${ }^{36}$ Архив внешней политки Российской Федерации (hereafter-AВПРФ), f. 0151 , op. 5 , d. $4,1.47$.

${ }^{37}$ Sidzikauskas to Galvanauskas, report of 20 Febr. 1923, LCVA, f. 383, ap. 7, b. $375,1.160$. 
Such a warning was the gentlest diplomatic mechanism, which, however, functioned almost continuously and was often practised by the Soviet Union and Germany simultaneously. On 25 June 1926, the German ambassador in Kaunas Erich Schroetter, as many times before, firmly promised his colleague from Moscow, Sergei Aleksandrovskii, that he would endorse any action directed against the rapprochement between Poland and Lithuania, and that that was the only German policy possible. ${ }^{38}$

Preventing Lithuania's negotiations with Poland on Vilnius, the Soviet Union and Germany at the same time avoided giving any guaranties, or committing themselves in any way to help Lithuania regain its capital in the future. And that was Lithuania's aim nearly throughout the entire period between the two World Wars.

In 1923, Lithuania took advantage of the favourable position of Germany and the Soviet Union and occupied the region of Klaipeda by force. Encouraged by the success, some of the politicians, first of all the leaders of the Nationalists and the Riflemen's Union Augustinas Voldemaras and Vincas Krevè, were thinking of regaining the area of Vilnius in the same way - by causing a real or assumed rebellion of the local population. They understood that their plan would not work without the German and especially the Soviet support. Therefore Voldemaras and Krevè suggested that the Soviet ambassador in Kaunas, Ivan Lorents, should create a joint Soviet and Lithuanian military underground organisation in the Vilnius Region, which would arrange an anti-Polish uprising. ${ }^{39}$ Soon the official Lithuanian ambassador in Moscow Baltrušaitis, too, made the Soviets similar offers, urging them to sign a treaty according to which they would commit themselves to assisting Lithuania in its defence against Poland and recapture of Vilnius. Even though the Soviets did not reject the suggestion, they gave the Lithuanians to understand that such commitments did not interest them.

Germany was also addressed with similar suggestions. In October 1923, a special delegation of the Riflemen's Union, apparently with the knowledge of the Lithuanian government, visited Germany and discussed with the diplomats and the military of that country a possibility of creating a defence union, however, they did not receive any positive reaction. Quite on the contrary: the German officers were unpleasantly surprised, they even considered it impudent that the representatives of

${ }^{38}$ Z. Butkus, 'Diplomatische Zusammenarbeit Deutschlands und UdSSR in den Baltischen Staaten 1920-1939', Litauisches Kulturinstitut. Jahrestagung 1998. (Lampertheim, 1999), 76.

${ }^{39}$ Z. Butkus, 'Bendrininkų kèslai', Darbai ir dienos, 21 (2000), p. 198 
a small country should dare take the initiative, give suggestions to a large and powerful country - if the latter would need and be interested in that, it could suggest itself. ${ }^{40}$

The Soviet Union and Germany disputed on how to react to the Lithuanian suggestions. At the end of 1923 the German ambassador in Lithuania, Franz Olsenhausen, went to Moscow, where he tried to find out whether it was worth committing oneself to Lithuania by a treaty and helping it to regain Vilnius. ${ }^{41}$ In short, both states decided that it was neither worthwhile nor purposeful. They wanted to have a free hand and only in the case of a military conflict to judge according to the circumstances and to make the final decision - to assist Lithuania or not, and if so, then how much and in what ways.

Later Lithuanian attempts to obtain a guaranteed support of Germany and the Soviet Union on the issue of Vilnius also ended in a failure. As a matter of fact, Lithuania, feeling insecure following the Pact of Locarno, tried to establish closer contacts with Germany and the Soviet Union and started intensive negotiations with the latter about a treaty of non-aggression. Lithuania endeavoured to make the Soviets commit themselves by this treaty or some other secret document to render it assistance against Poland and in case of war or conflict to regain Vilnius. Howerer, the Soviets disagreed and after lengthy negotiations Lithuania had to sign a treaty of non-aggression with no guaranties in it in 1926 . That treaty only reasserted that the Peace Treaty of 1920 was still valid, and so were each of its articles, including the assignment of Vilnius to Lithuania. ${ }^{42}$

The Lithuanian Prime Minister, Voldemaras, (1928-9) and President Antanas Smetona (1934-5) still attempted to negotiate a guaranteed (not declarative) recovery of Vilnius with the aid of the Soviet Union, but they both failed.

The Soviet Union and Germany avoided committing themselves to Lithuania because of one more reason - they feared that, if they did that, Lithuania would become more independent and may even provoke war with Poland over Vilnius, a war, for which neither of the great powers were ready, they were only intensively preparing for it.

While instigating the Lithuanian-Polish conflict, the Soviet Union and Germany at the same time took care for it not to turn into a war. It was a kind of attempt to control a normal temperature of the conflict -

${ }^{40}$ ADAP, Serie A, Bd. 9, S. 569-570.

${ }^{41}$ Records of the discussions, АВПРФ, f. 0151, op. 16, p. 32, d. 3, 1. 111.

${ }^{42}$ For more on this topic, see A. Kasparavičius, Didysis X Lietuvos užsienio politikoje (Vilnius, 1996). 
neither too high nor too low. In other words, the conflict was controlled escalated until the end of 1926, suppressed in 1927-8, then again incited.

Actually, the Lithuanian-Polish conflict over Vilnius intensified particularly in 1927. Poland's policy posed a threat to the security of Lithuania - it could be occupied in one sudden attack, and the conflict would end. This outcome was acceptable neither for the Soviet Union nor for Germany. Therefore they started insisting that Lithuania must be more flexible, less categorical on regaining Vilnius and not considering itself of being at war with Poland.

The disputes on the Vilnius question in the international politics in 1927 have been dealt with extensively in the works by Pagel and Laurinavičius. ${ }^{43}$ Agreeing in essence with these historians, I still would add that the archival data gathered by me show that the collaboration between Germany and the Soviet Union regarding Vilnius has been much more intimate than it has been usually thought. Besides, the attitude of Germany was much closer to that of the Soviet Union rather than of the Allied Powers, and the Soviet Union played a more decisive role in the diplomatic games than it has been considered until now.

Here is one episode of the diplomatic activities of 1928, which is typical of the roles of the great powers in the Vilnius dispute. That was the year when the Lithuanian-Polish conflict was rather bitter. Lithuania continued evading negotiations with Poland until the solution of the Vilnius problem, and the great Western powers threatened to resort to resolute actions against Lithuania an the September session of the Council of the League of the Nations. At the beginning of July the French, British and Italian ambassadors in Kaunas were instructed by their governments to demand in joint démarche the Lithuanian Prime Minister and Minister of Foreign Affairs Voldemaras to be more flexibly disposed towards Poland. There were plans to incorporate the German ambassador in Kaunas Hans Ludwig Moraht into the démarche, too. He, however, declined the suggestion and informed about it the Soviet ambassador in Lithuania, S. Rabinovich. On 14 July, the two had an lengthy discussion. Rabinovich urged Moraht 'in no way to get involved' in the common 'démarche' of the Western countries ${ }^{44}$ but to work together with him. The latter agreed, he only said that he would have to go to a meeting with the French, British and Italian representatives on 16 July. Rabinovich did not object to that, but gave detailed instructions on how to act at the

${ }^{43}$ Č. Laurinavičius, 'Augustino Voldemaro užsienio politika ir Lietuvos geopolitika 1927-1929 m.', Politika, pp. 188-226.

${ }^{44}$ The record of the talk between Moraht and Rabinovich of 14 Aug. 1928, АВПРФ, f. 0151, op. 16, p. 32, d. 3, 1. 295. 
meeting. Moraht was advised to keep a low profile, not to start the conversation first, to let others present their opinions and find out what instructions they had from their governments. In Rabinovich's words, the French representative 'will be the first to speak; being French he is impatient'.

Moraht promised to obey that wise advice and he really did.The meeting took place on 16 July just as Rabinovich had mentioned. The French diplomat spoke the first, and he vehemently attacked Lithuania. Moraht did not defend it, he only said that Poland was no saint either. The Italian representative partly agreed with him. The British diplomat proposed to present a 'joint memorandum' to Voldemaras. Moraht strictly rejected the suggestion. He stated that he would never sign it and he would not take part in the demarche as well. He did not say anything about his actions, but he found out when and how the other diplomats were going to talk to Voldemaras.

On 19 July Moraht gave a detailed report on that to Rabinovich. On 19 July and as previously on 14 July the two decided on when, how and what to inform Voldemaras and other Lithuanian politicians. Morath and Rabinovich decided to emphasize that the September session of the Council of the League of the Nations may become threatening for Lithuania, and Germany, even as a member of the Council, would not be able to help it in any way, if Lithuania continued escalating the problem of Vilnius and did not regulate at least several 'technical' questions with Poland. It was decided to state categorically that Voldemaras should not think that, in case of a Lithuanian-Polish war, the Soviet Union and Germany would at once, regardless of the situation, defend Lithuania. His hopes that 40-50 thousand German volunteers would come to defend Lithuania are groundless. If the best case he might expect some 20-30 individuals.

In those conversations Moraht was extremely frank, he even showed Rabinovich some top secret diplomatic documents. On 19 July ${ }^{45}$ Moraht read Rabinovich his whole telegram, which he had just prepared to dispatch to Berlin, and even asked him whether there was something else to add. ${ }^{46}$ It was by far not the only case of the diplomatic collaboration between the Soviet Union and Germany in dealing with the issue of Vilnius. In addition to the usual diplomatic channels, other methods were used for the regulation of that problem as well. In the middle of July 1928, Boris Stomoniakov, a member of the Board of the People's Commissariat of the Foreign Affairs of the Soviet Union, who was actually in charge of the relations with the

${ }^{45}$ Ibid., 1. 308-311.

${ }^{46}$ Ibid., 1. 311. 
Baltic States, went to Berlin with a special mission. In the presence of the Soviet ambassador in Berlin Nikolai Krestinskii he talked with the Secretary of the German Ministry of Foreign Affairs Schubert about how to make Lithuania withhold the issue of Vilnius, and at the same time to leave the question unsolved. ${ }^{47}$

In September 1929, following Voldemaras' resignation, the Lithuanian-Polish conflict eased and became less intense. Therefore the Soviet Union and Germany quickly changed their position. They no more suppressed the conflict, instead they now instigated it, and, acting together, vigilantly prevented its peaceful resolution. The Soviets were particularly attentive. For example, they endeavoured to neutralize the Lithuanian attempts to negotiate with Poland without firmly insisting on the immediate return of Vilnius in 1934-5. Distrusting the later Lithuanian Foreign Ministers, Dovas Zaunius and Stasys Lozoraitis, the Soviets mainly controlled the conflict of Vilnius through Prime Minister Juozas Tubelis and President Antanas Smetona. ${ }^{48}$

Lithuania had to take Soviet opinion into consideration for one more reason. It could no longer rely on Germany's position, as the latter had signed a non-aggression pact with Poland in January 1934, and now still more categorically avoided raising the issue of Vilnius. Germany even supported the anti-Lithuanian policy of Poland. In March 1938, when Poland categorically insisted on Lithuania's entering into diplomatic relations with it, Germany refused to be an intermediary in regulating the conflict between these countries. It even intended to occupy the area of Klaipeda and some other western Lithuanian lands in case of the Polish army's invasion into Lithuania. ${ }^{49}$ Germany actually allowed Poland to deal freely with Lithuania. It was a kind of compensation to Poland for not contradicting the Austrian Anschluss.

Just like the other great powers, the Soviets also advised Lithuania to accept the Polish ultimatum of 1938, because they were not yet ready for a war, which could have broken out, if the ultimatum had been rejected, and then they would have either to effectively support Lithuania, or their widely advertised policy of support would have been exposed. Besides, they did not want Poland to grow stronger after Lithuania's occupation. It was not due to the Soviet diplomatic assistance to Lithuania, as the Soviet historians used

${ }^{47}$ Ibid., 1. 313.

${ }^{48}$ Z. Butkus, 'Stasys Lozoraitis sovietų diplomatų akimis', Lietuvos diplomatija XXa. (Vilnius, 1999), p. 83-91.

${ }^{49}$ Žepkaitè, Diplomatija, p. 258-260; Lossowski, Stosunki polsko-litewskie 1921-1939; p. 323-324; J. Pagel, Polen und die Sowjetunion, p. 54-55. 
to state,${ }^{50}$ but due to Lithuania's compliance that the war was avoided, as Lithuania accepted the ultimatum without reservation. That is clearly demonstrated by the aforementioned Pagel's monograph, presenting a detailed analysis of the Soviet diplomatic relations with Lithuania and Poland at the time of the ultimatum. True, as a result of Soviet pressure Poland stopped insisting on Lithuania's official refusal of its claims to Vilnius, and only categorically required the establishment of diplomatic relations.

Nevertheless, even after the acceptance of the ultimatum, the issue of Vilnius remained unsolved, and that was what both the Soviet Union and Germany were striving for. In 1938, just like in 1927-8, they again temporarily suspended the Polish-Lithuanian conflict over Vilnius, but not try to solve it definitely. They again used that problem in the fateful year of 1939, when they divided the Baltic States and Poland into the spheres of influence. While dealing with the Vilnius question, the Soviet Union and Germany acquired a great deal of diplomatic experience, applying which they easily and quickly carried out the fateful partition.

While preparing for war and a new Western expansion, the Soviet considered Vilnius to be an important strategic point, a bridgehead. In the well-known talks with Great Britain and France in 1939 they insisted on their allowing the Red Army to occupy 'the Vilnius region' in case of war and to advance westward through the so-called 'Vilnius corridor'. ${ }^{51}$ As this and other impudent demands were rejected, the Soviets again turned to their traditional ally, Germany, and made a foreboding plot with it. The first article of the secret protocol of the Non-aggression Treaty, signed on 23 August 1939, emphasized that the Soviet Union and Germany acknowledge "the Lithuanian interests in the Vilnius land'. ${ }^{52}$ Of course, a real acknowledgement of the Lithuanian interests should not even be mentioned here, as Lithuania itself was treated as a sphere of Germany's interests. Vilnius was mentioned in the secret protocol only in order to make it clear the size of the territory of Lithuania assigned to Germany - with or without Vilnius.

True, the eastern borders of that territory (the Vilnius Region) do not seem to be clearly stated. On 9 September 1939, when asked

${ }^{50} \mathrm{~K}$. Navickas, TSRS vaidmuo ginant Lietuva nuo imperialistinès agresijos 1920-1940 metais (Vilnius, 1966), p. 201-220 ff.

${ }^{51}$ J. Pagel, Polen und die Sowjetunion, p. 260.

${ }^{52}$ ADAP, Serie. D, Bd. 7, S. 206; Suokalbis. 1939-1941 metu dokumentai apie Stalino ir Hitlerio nuosprendi likviduoti Lietuvq ir kitas suverenias valstybes (Vilnius, 1989), p. 16. 
by the Lithuanian ambassador in Berlin Kazys Škirpa, which territories were assigned to Lithuania in Moscow, Bruno P. Kleist, an official of the German Ministry of the Foreign Affairs, did not know what to answer. Škirpa told him that the legal eastern border of Lithuania was the one that was indicated in the Peace Treaty with Russia in 1920, and gave him a map of the border. ${ }^{53}$ Two days later, on 11 September, having had the situation explained and, obviously, having consulted Moscow, Kleist told Škirpa that Lithuania was claiming too large a territory, which it would not manage to control either politically or militarily. It should only occupy 'Vilnius and a territory around it', and to discuss the exact borders with Germany and the Soviet Union. $^{54}$

Presumably, in September 1939, Germany and the Soviet Union only decided to assign Vilnius to Lithuania, but did not determine the exact size of the surrounding territory. Only one thing is clear - the amount of territory, which had been indicated in the Peace Treaty of 1920, was not planned for Lithuania. Most probably it could only expect to have as much territory in the east as it has today, i.e., as much as Stalin assigned it in 1939. Germany itself did not consider it necessary for Lithuania to lay claim to a larger Vilnius area, since Lithuania, as a sphere of German influence, already protruded very much eastwards, Latvia and a large part of Poland being assigned to the Soviet Union.

After obtaining the Soviet approval to include the whole of Lithuania into its sphere of influence, Germany started urging Lithuania to take Vilnius by force as its rightful territory and its capital city. In the opinion of German politicians, if Lithuania started military actions against Poland, it would be easier for Germany to occupy the latter, besides, the world would think that the Germans were not the only neighbours of Poland who could not live in peace with it any longer. Howerer, the most important thing was, that by taking Vilnius by force, Lithuania would have become a military ally of Germany, its accomplice, and therefore it would be easier for Germany to turn Lithuania into its satellite, take it into its sphere of influence, to thrust on it one kind of protectorate or another. Having regained Vilnius with Germany's approval and support, Lithuania would have been grateful to it and stop resisting its influence. Thus, there were intentions to exploit the issue of Vilnius as a comfortable means for the occupation of Lithuania.

On 29 August 1939, while making the final diplomatic preparations for the attack on Poland, the German Minister of Foreign

${ }^{53}$ K. Škirpa, Lietuvos nepriklausomybès sutemos (Vilnius, 1996), p. 196,

${ }^{54}$ ADAP, Serie. D, Bd. 8, p. 42-43. 
Affairs Ribbentrop, instructed the German ambassador in Kaunas, Erich Wilhelm Zechlin, to make a statement reminding the Lithuanian Government of 'the hopes of the Lithuanian nation' to regain 'Vilnius, occupied by the Poles' ${ }^{55}$ On the same day the German State Secretary Ernst Freiherr Weizsacker, also instructed Zechlin 'to carefully inquire' whether the Lithuanian government could make 'special demonstrations, concentrating its troops at the Polish border' ${ }^{56}$ On the next day, 30 August, Weizsacker again asked Zechlin, 'even emphatically than it is required in Ribbentrop's instruction of 29 August', to stress the German sympathy with the 'Lithuanian attempts' to regain the Vilnius area and to tell them that in case of 'territorial changes between Germany and Poland it would be possible to consider seriously the Lithuanian claims' to that territory. ${ }^{57}$

Zechlin accurately followed the instructions from Berlin. On 29 August he was already talking to the Deputy Prime Minister Kazys Bizauskas, at that time also acting as Minister of the Foreign Affairs. However, neither Bizauskas, nor many of the other Lithuanian officials submitted to the German pressure, because they were certain that in case of war Lithuania had to maintain its strict neutrality and in no way to enter the war against Poland on the side of Germany. On 31 August, Zechlin disappointedly wrote in his report to Berlin:

The Prime Minister Černius in his speech ... declared that Lithuania would adhere to its policy of neutrality. Also, Bizauskas, to whom I proposed to organize a military demonstration at the Polish border, $\ldots$ avoided talking about that, he only responded that General Raštikis informed in secret the [German] military attaché about the measures taken by Lithuania. ${ }^{58}$

However, the mention of the Commander-in-Chief of the Lithuanian army Stasys Raštikis was a mere manoeuvre of Bizauskas, his evasion of giving a direct negative answer. Raštikis stated it more clearly by saying to the German military attaché Emil Just that Lithuania wanted to avoid any military demonstrations against Poland and would only strengthen the borders with it. ${ }^{59}$ At the end of his report Zechlin was quite right in evaluating the Lithuanian attitude of that time:

The Lithuanian Government tends to avoid conflict with Poland at the moment. A part of the Lithuanian society is expecting to regain Vilnius, whereas the rest, including the Government itself,

\footnotetext{
${ }^{55}$ ADAP, Serie. D, Bd. 7, S. 337-338.

${ }^{56}$ Ibid., p. 353.

${ }^{57}$ Ibid., p. 375.

${ }^{58}$ Ibid., p. 389.

${ }^{59}$ Ibid.
} 
are, quite on the contrary, well disposed towards England and

France, if not Poland itself. I am continuing my work according to the instructions 29 and 30 of August. ${ }^{60}$

It was, of course, not a part, but the whole of Lithuanian society that still wanted to regain Vilnius, but not at such a cost, not by starting war against Poland together with fascist Germany branded as an aggressor.

Following the German attack on Poland on 1 September, Lithuania was pressured into occupying Vilnius. On the instructions of Ribbentrop, the German military leadership and even Hitler himself, Zechlin and Just many times discussed this question not only with the Lithuanian diplomats, but also with the Prime Minister Jonas Cernius, the Commander-in-Chief Raštikis, the Minister of Defence Kazys Musteikis during the period between 1 and 13 of September. Despairing attempts were made to convince them that it was a wonderful, hardly ever again recurring opportunity to regain Vilnius, and that now Lithuania could do it quite easily, as nearly all the Polish troops were withdrawn from the Vilnius area to fight against the Germans. Besides, the march of the Lithuanian army to Vilnius would be gladly supported by the German air force, tanks, heavy artillery, and the Soviet Union would not object to that as the matter had already been discussed. ${ }^{61}$

However, the Lithuanian government of that time withstood the pressure, President Antanas Smetona even managed to avoid the meeting with Zechlin, though the latter tried hard to have it and was ready for a decisive conversation. In response to the German encouragement Lithuanian politicians answered that Lithuania by no means refused Vilnius, and continued to treat it as its capital and its rightful territory, however, it could in no way abandon its neutrality, which it had emphatically declared by a presidential decree on the first day of the war - 1 September.

Historical scholarship emphasises that Lithuania first of all refused to occupy Vilnius at the beginning of the war because it feared the reaction of England and France and yielded to their pressure. Actually, that pressure was strong. England and France were the allies of Poland, they threatened that they would break off diplomatic relations with Lithuania, and even declare war on it, if only it accepted the German proposal and tried to take back Vilnius from Poland. ${ }^{62}$

${ }^{60}$ Ibid.

${ }^{61}$ ADAP, Serie D, Bd. 8, S. 27, 30, 42-43, 48-49; S. Raštikis. Kovose dèl Lietuvos, d. 1 (Los Angeles, 1956), p. 591-593; K. Musteikis, Prisiminimufragmentai (Vilnius, 1989), p. 25-28 ff.

${ }^{62}$ R. Žepkaitè, Vilniaus istorijos atkarpa. 1939-1940 (Vilnius, 1990), p. 22. 
However, those threats were not effective enough as a counterpoise to the German urging and forcing to occupy Vilnius. During the whole period between the two World Wars Lithuania took little notice of the British and French attitudes towards the Vilnius issue. Soviet influence should not be overestimated as well. ${ }^{63}$ Of course, it was not in the interests of the Soviet Union to see Vilnius occupied by Lithuania and the German sphere of influence extended far to the East, however, they only suggested in a very gentle, careful and indirect manner that Lithuania should not do that, as they were bound by secret agreements with Germany. Frequently the Lithuanian politicians could hardly see any clearer Soviet attitude towards the question of regaining Vilnius.

The decision not to yield to German pressure and not to occupy Vilnius by force was made by Lithuania on its own and rather independently. There were two major motives. Firstly, President Smetona and most of the other Lithuanian politicians understood that Germany would lose the war in the end, and therefore Lithuania could in no way be its ally. Vilnius had to be regained peacefully, actively participating in the post-war peace conference. Prime Minister Černius even mentioned that in a conversation with Zechlin on 14 September. ${ }^{64}$ Secondly, from the moral point of view, it was impossible to take Vilnius by force from the heavily bleeding Poland, desperately fighting against the Nazi Germany. It could have been taken for a stab in the back. The Commander-in-Chief Raštikis wrote in his memoirs that at that time "the honour of the nation and the political reality' made the march to Vilnius impossible. ${ }^{65}$ Lithuanian politicians, horror-stricken, recalled a similar situation, when Poland tore the disputed region of Cieszyn (Teschen) from Czechoslovakia, which was occupied by Germany. That action was described by the contemporaries in the following way: 'Hyenas eat carrion'. The Lithuanian leaders shied away from a similar situation. The well-known Latvian historian Edgars Andersons wrote that by refusing to occupy Vilnius in September 1939, "the Lithuanians showed the world their moral dignity'. ${ }^{66}$ Some foreign observers found this Lithuanian behaviour rather difficult to understand, because at that time it was usual to grab anything one could get. A Swedish journalist, greatly surprised, called Lithuanians 'the nation of the highest civilisation' in Europe. ${ }^{67}$

\footnotetext{
${ }^{63}$ Such exaggeration is evident in K. Navickas' TSRS vaidmuo, p. 270-271.

${ }^{64}$ ADAP, Serie D, Bd. 8, S. 48-49.

${ }^{65}$ Raštikis, Kovose del Lietuvos, p. 592.

${ }^{66}$ E. Andersons, Latvijas vēsture. Ärpolitika 2 (Stockholm, 1984), p. 188.

${ }^{67}$ Ibid.
} 
Lithuanian politicians were persistent and keen while evading German pressure for one more reason. They already had the immunity against that, as they could not forget how brutally with categorical threats Germany tore away the Klaipeda Region in the spring of 1939. The Minister of Foreign Affairs, Juozas Urbšys, this time managed to avoid a secret meeting with Ribbentrop, who had invited him to Gdańsk (Danzig), the German military headquarters on 21 September. The meeting was approved by the President and the Government at its session of 22 September. However, as on the same day Urbšys told Zechlin that the meeting should be announced publicly and that Lithuania intended to strictly adhere to its neutrality and to remain 'free and independent', ${ }^{68}$ Ribbentrop postponed the meeting, which actually meant that it was cancelled.

Urbšys' presentiment of danger, his unwillingness to go to the meeting was not groundless. According to the extant documents, at that meeting, Ribbentrop was going to make Urbšys sign a GermanLithuanian 'treaty of defence', a project of which was prepared on 20 September. The project shows that Lithuania really had to be turned into a German satellite. The first article of the intended treaty read that the Reich granted Lithuania its 'protection', without violating its 'state independence' ${ }^{69}$ Of course, 'without violating' was just an empty phrase, as both sides had to sign a military convention, which stated that 'the size, dislocation and provisions of the Lithuanian army' would be determined in agreement with the German military leadership. A German military mission was to be sent to Kaunas in order to implement the convention. ${ }^{70}$

Thus, the Lithuanian military forces were to be completely subordinated to the German military affairs. A similar fate could have awaited Lithuanian economics, as the third article of the treaty specified a 'radical' development of the economic relations of both sides. ${ }^{71}$ The treaty without doubt would have paralysed Lithuanian sovereignty, even though it might not seem as dangerous as the one that Lithuania had to sign with the Soviet Union on 10 October of the same year. The Germans did not plan to station their troops in Lithuania or establish their military bases there, besides, Urbšys might

${ }^{68}$ ADAP, Serie D, Bd. 8, S. 94-95; K. Škirpa, Lietuvos nepriklausomybès sutemos, p. 226; J. Urbšys, Lietuva lemtingaisiais 1939-1940 metais (Vilnius, 1988), p. 21; J. Urbšys, Lietuva ir Tarybu Sajunga lemtingaisiais 1939-1940 metais (Kaunas, 1987),. p. 3-4.

${ }^{69}$ ADAP, Serie D, Bd. 8, S. 87.

${ }^{70}$ Ibid.

${ }^{71}$ Ibid. 
have managed to negotiate a more favourable treaty than the German project. Most probably, his visit was cancelled because Ribbentrop got some news about the unwillingness of the Lithuanian leaders to capitulate.

Intending to enforce a treaty of obedience on Lithuania, German politicians expected to make use of the Vilnius factor. Even though Lithuania refused to occupy it, they still thought that Vilnius must belong to it. After Vilnius was occupied by the Red Army on 19 September, two days later, on 21 September, Ribbentrop instructed the German ambassador in Moscow, Friedrich Werner von Schulenburg, to urgently meet Stalin and Molotov, and remind them that according to the secret agreement Vilnius must go to Lithuania. ${ }^{72}$ However, having occupied Vilnius, the Soviets, did not want the city to slip out of their hands. On 22 September, in response to Schulenberg's statements about Vilnius, Molotov said that the time was not ripe yet to transfer the city to Lithuania, and that the problem of Vilnius belonged to the common complex of the Baltic problems, the final solution of which had take place in its entirety and at the same time. ${ }^{73}$

This phrase, though mysterious, shows that the Soviets had plans to use the occupied Vilnius for overtaking the whole Lithuania from the German sphere of influence into theirs. Already on 25 September Stalin and Molotov offered Schulenberg in the Kremlin to switch the spheres of influence so that Lithuania would go over to the Soviets, and an even greater part of Poland (the Lublin voivode and a part of the Warsaw voivode up to the River Bug) would go to Germany. ${ }^{74}$ This offer was confirmed by the secret protocols of 28 September.

Of course, that was a mere bargain between the two conquerors. However, the Germans were unwilling to relinquish Lithuania, they did it 'with a heavy heart', in Ribbentrop's words. ${ }^{75}$ Howerer, they had to do that partly because of Lithuania's not taking Vilnius Germany could find no appropriate way to turn the country into its satellite quietly, simply 'elegantly' without an international scandal. As the Soviets were preparing to attack Poland, on 16 September Molotov asked Schulenberg whether an agreement had been reached with Lithuania 'about the Vilnius Region, in particular about who should occupy the city', the latter had nothing to say. ${ }^{76}$ Lithuania's disobedience

${ }^{72}$ ADAP, Serie D, Bd. 8, S. 88.

${ }^{73}$ Ibid., p. 96.

${ }^{74}$ Ibid., p. 101.

${ }^{75}$ И. Риббентроп. Между Лондоном и Москвой. Воспоминания и последние записи. (Москва, 1996), с. 158.

${ }^{76}$ ADAP, Serie D, Bd. 8, S. 60. 
to the German diktat made the Nazis rather angry, and on 14 September they decided to stop forcing Lithuania to occupy Vilnius. ${ }^{77}$ On 16 September Zechlin received a strict instruction from Berlin 'to cease (abzuschneiden)' negotiating with the Lithuanian politicians about the occupation of Vilnius. ${ }^{78}$ Their disobedience really irritated the Germans. On 17 September the Lithuanian ambassador in Berlin was called to the German Ministry of Foreign Affairs, where he was acquainted with the protest of the Government of the Reich, in which Lithuania was blamed for complaining to England and France about Germany's making it fight against Poland instead of occupying Vilnius. At the end of the statement it was emphasized that Germany would make 'its own conclusions' about such behaviour of Lithuania. ${ }^{79}$

Lithuania managed to withstand the pressure of one of the aggressors, and not to fall into its snare, but it could do nothing against the two aggressors working hand in hand. By the treaty of 10 October 1939, the Soviet Union managed to get the right to deploy its military bases on the territory of Lithuania in return for Vilnius. Contemporaries were sharp-witted in estimating this situation as 'Vilnius müsu, o mes rusu' (Vilnius is ours, but we are annexed to Russia).

The question is often raised, whether, by obeying Germany and occupying Vilnius, Lithuania would have managed to avoid the Soviet occupation and to preserve its independence. Škirpa gives a positive answer in his memoirs. In 1939 he was the ambassador in Berlin, and endeavoured to make Lithuania obey Germany and march to Vilnius. ${ }^{80}$ In such a case the Soviet occupation probably could have been avoided, however, undoubtedly the country would have become dependant on Germany (and that was clearly attested by the project of the treaty prepared on 20 September) and would have lost the honour of the nation, so hard to recover.

\section{Conclusions}

The Lithuanian-Polish conflict over the Vilnius Region was not merely an ethnic conflict. It did not arise because of the discord between the two nations, nor because of some clashes or outbursts of violence by the population at the border. First of all, it arose because of the political situation, the attempts of Poland to re-establish the common historical state with Lithuania incorporated, and to act, or at least pretend to act, as a great power.

77 Ibid., p. 43.

${ }^{78}$ Ibid., p. 58.

${ }^{79}$ Ibid., p. 65; K. Škirpa, Lietuvos nepriklausomybès sutemos, p. 216.

${ }^{80}$ Ibid., p. 151-240. 
Germany and the Soviet Union created the conditions for the escalation and continuance of the conflict. By letting the Polish army march on Vilnius and not helping Lithuania to recover it, Germany indirectly assisted Poland in establishing itself in the capital of Lithuania in 1919. By assigning Vilnius to Lithuania under the Peace Treaty of 1920 , and then actually to Poland by the Peace Treaty of 1921, the Soviets set a trap of international law, in which both sides were caught. Besides, in 1920 they prevented the organization of a referendum in the Vilnius Region, and in 1921 they disrupted the Hymans project and did not allow the Western countries to solve the conflict in a compromise through negotiation.

Having created favourable conditions for the Lithuanian-Polish conflict over Vilnius, Germany and the Soviet Union controlled it throughout the entire period between the two World Wars and did not let it subside. They usually exacerbated it, but at times (1927-1928 and 1938) they also curtailed it, as they did not a war to start before they were ready for it. They worked hand in hand while regulating the conflict.

Inciting the Lithuanian-Polish conflict over Vilnius, the Soviet Union and Germany weakened the unity of the Baltic States, disrupted their security, prevented the establishment of a defence union, and respectively kept those states separate, nearly isolated, and not prepared for the aggression of their neighbours. While controlling the Vilnius problem, the Soviet Union and Germany acquired a fair amount of diplomatic co-operation, which was effectively applied in dividing the Baltic States into spheres of influence in 1939.

Rejecting the Nazi proposal to recapture Vilnius by force in 1939, Lithuania avoided becoming a sphere of German influence. However, soon it had to accept Soviet military bases in return for the capital city. It was only the collaboration of the two great neighbours that brought the Baltic States to their knees. Having sacrificed its interests for the sake of Poland and Western democracies in 1939, Lithuania was not saved by the same democracies from the occupation in 1940. They neither let Lithuania protect its interests, nor minded those interests themselves. Most probably that was the reason why during the June uprising of 1941 Lithuania made little effort to get rid of German influence.

The attitudes of the Soviet Union and Germany towards the issue of Vilnius between the two World Wars still remain an urgent historical experience, reminding us that backstage influences may also be relevant to the politics of the great powers in today's international conflicts. 


\section{Author Details}

Zenonas Butkus, Doctor of History, graduated from the University of Vilnius in 1979. Ever since then he has been working at the University, and recently as a prodean of the Faculty of History. His field of research is the international situation of the Baltic States in the period between 1918 and 1940.

Address: Faculty of History, University of Vilnius, Universiteto 7, 2734 Vilnius, Lithuania Email: if@if.vu.lt

\section{SSRS IR VOKIETIJOS POŽIŪRIS I VILNIAUS PROBLEMĄ TARPUKARYJE}

Santrauka

\section{ZENONAS BUTKUS}

Šiame straipsnyje, remiantis daugiausia neskelbtais dokumentais iš Lietuvos, Latvijos, Estijos bei Vokietijos ir SSRS archyvu, nagrinejjamos SSRS ir Vokietijos pažiūros i Vilniaus problemą tarpukaryje. Paaiškinama, kad ta problema galutinai susiformavo po Pirmojo pasaulinio karo, kai Lenkija jèga užėmé Lietuvos sostinę ir išlaikè ją savo valdžioje beveik visą tarpukari. Lietuva su tuo nesusitaikè, ir tarp abiejų šalių kilo konfliktas, kuri kurstė SSRS ir Vokietija, norédamos neleisti, kad Baltijos šalys ir Lenkija sukurtų gynybinę sajungą.

SSRS ir Vokietija ginčą dèl Vilniaus kotroliavo ir prižiūrèjo veikdamos kartu, sutartinai. Reguliuodamos Vilniaus problemą, jos sukaupé nemažą diplomatinio bendradarbiavimo patyrimą, kurị veiksmingai panaudojo 1939 m., pasidalindamos itakos sferomis Baltijos valstybėse.

Received 20 May 2000 